\title{
Trait Emotional Intelligence and Leadership Self-Efficacy: Their Relationship with Collective Efficacy
}

\author{
José J. Villanueva ${ }^{1}$ and José C. Sánchez ${ }^{2}$ \\ ${ }^{1}$ Universidad Autónoma de Tamaulipas (Mexico) \\ ${ }^{2}$ Universidad de Salamanca (Spain)
}

\begin{abstract}
In this article, a leadership model is presented, with which to investigate the relationship of trait emotional intelligence (trait EI), leadership self-efficacy and leader's task self-efficacy with collective task efficacy and group performance. The sample was made up of 217 undergraduate students, randomly assigned to work teams of 1 leader and 2 followers that were requested to perform a production task. An adapted version of the Schutte Self-Report Inventory (SSRI; Schutte et al., 1998) was used to measure trait EI. Structural equation modeling was used to test the hypothesized relationships. Results indicated that task self-efficacy was a mediator between leadership self-efficacy and collective task efficacy; the latter, in turn, was the best predictor of group performance. No significant relationship was found between trait EI and collective task efficacy although, unexpectedly, trait EI was positively associated with leadership self-efficacy. Implications of the results are discussed.

Keywords: leadership self-efficacy, trait emotional intelligence, collective efficacy, group performance
\end{abstract}

Presentamos un modelo de liderazgo para examinar las relaciones entre la inteligencia emocional rasgo, la autoeficacia para el liderazgo y la autoeficacia para la tarea del líder con las creencias de eficacia colectiva para la tarea y el desempeño grupal. La muestra fue compuesta por 217 estudiantes universitarios que fueron asignados al azar a equipos de trabajo conformados de 1 líder y 2 seguidores para llevar a cabo una tarea de producción. Para medir la inteligencia emocional rasgo se empleó una versión adaptada de la escala Schutte Self-Report Inventory (Schutte et al., 1998). Para verificar las hipótesis principales, se utilizó un modelo de ecuaciones estructurales. Los resultados indicaron que la autoeficacia del líder para la tarea fue una variable mediadora entre la autoeficacia para el liderazgo y la eficacia colectiva para la tarea; ésta a su vez fue la mejor predictora de la desempeño grupal. La IE rasgo no tuvo relación con la eficacia colectiva para la tarea pero, en una dirección no esperada, la IE rasgo se asoció positivamente con la autoeficacia para el liderazgo. Se comentan las implicaciones de los resultados.

Palabras clave: autoeficacia del líder, inteligencia emocional rasgo, eficacia colectiva, desempeño grupal

Correspondence concerning this article should be addressed to: José C. Sánchez Universidad de Salamanca, Facultad de Psicología, Avda. de la Merced, $n^{\circ}$ 109/131, 37005, Salamanca, Spain.

Translation: Virginia Navascués Howard 
Recent scientific interest in the concept of emotional intelligence has attempted to unveil the mystery of whether there is a Factor " $X$ " that will complete our knowledge of interpersonal influence and leadership (Brown \& Moshavi, 2005). The term "emotional intelligence" (EI) was formally presented in 1990 with the publication of Salovey and Mayer's (1990) article Emotional Intelligence in the journal Imagination, Cognition and Personality, where they defined it as "...a subset of social intelligence that involves the ability to monitor one's own and others' feelings and emotions, to discriminate among them, and to use this information to guide one's thinking and actions." According to these authors' model and their subsequent revision (Mayer \& Salovey, 1997), an emotionally intelligent person is capable of recognizing emotional information and of performing abstract reasoning using this emotional information.

With regard to measurement of EI, Mayer and colleagues (Mayer, Salovey, \& Caruso, 2000) established a classification of EI models, called ability or mixed models, depending on whether or not they included in the theoretical definition some characteristics not considered mental skills (i.e., personality traits), although such definitions are generally complementary rather than contradictory (Ciarrochi, Chan, \& Caputi, 2000). In addition to the conceptual distinctions, there are also various instruments to assess EI. Some authors (see Daus \& Ashkanasy, 2005; Extremera, Fernández-Berrocal, Mestre, \& Guil, 2004) propose a category of measuring instruments based on three main criteria: (a) instruments based on the ability model of EI and that use measurements developed by its authors (e.g., the Mayer-Salovey-Caruso Emotional Intelligence Test, MSCEIT; Mayer, Salovey, \& Caruso, 2001; and the Multifactorial Emotional Intelligence Scale, MEIS [precedent of the MSCEIT]; Mayer, Caruso, \& Salovey, 1999); (b) instruments based on Salovey and Mayer's (1990) original formulation but which adopt a self-report methodology or an external assessment methodology (e.g., the Schutte Self-Report Inventory, SSRI, Schutte et al., 1998; the Trait Meta-Mood Scale, TMMS, Salovey, Mayer, Goldman, Turvey, \& Palfai, 1995); and (c) measuring instruments that include dimensions or components not included in Salovey and Mayer's original definition of EI (e.g., the Bar-on Emotional Quotient Intelligence, EQ-I, Bar-On, 1997; the Emotional Competence Inventory, ECI, Boyatzis, Goleman, \& Rhee, 2000).

These distinctions have led researchers to analyze more objectively the psychometric properties of some EI scales. With regard to the divergent validity of some self-report EI measures and cognitive skills, low or null correlations were found (Barchard, 2003; Derksen, Kramer, \& Katzko, 2002; Goldenberg, Matheson, \& Mantler, 2006), whereas measures of EI ability correlate modestly with cognitive skills (Van Rooy \& Viswesvaran, 2004). Together with the fact that self-report measures of trait EI and ability EI have very low correlations (Brackett \& Mayer, 2003; Brackett \& Salovey,
2006; Lopes, Salovey, \& Straus, 2003), this indicates the possibility that they may, in fact, be measuring two different constructs.

Petrides and Furnham's (2001) proposal has recently received empirical support (O'Connor \& Little, 2003; Warwick \& Nettelbeck, 2004). These authors suggest that the main difference among the EI models lies in the measurement of the construct. That is, there are two kinds of EI: (a) EI ability (or cognitive-emotional ability), assessed in maximum performance tests, and (b) trait EI (or emotional self-efficacy), which comprises self-report measures (for a review on the classification of trait EI, see Pérez, Petrides, \& Furnham, 2005).

Considering these basic facts, in this work, we have used the term trait EI to refer to emotional intelligence, because we are using a self-report instrument, the SSRI (Schutte et al., 1998).

After the concept of EI had been introduced and assessment measurements developed, researchers began to hypothesize about the possible links between EI and leadership (Caruso, Mayer, \& Salovey, 2002; George, 2000). Some empirical works have presented evidence of a positive relation between EI and leadership effectiveness (Kerr, Garvin, Heaton, \& Boyle, 2006; Leban \& Zulauf, 2004; Rosete \& Ciarrochi, 2005; Wong \& Law, 2002), and of the potential use of EI in organizational studies (Law, Wong, \& Song, 2004).

Particularly, transformational leadership (TL) style has been the focus of several recent investigations on EI and leadership, and evidence of the relationship between EI and TL has been reported (Downey, Papageorgiou, \& Stough, 2006; Mandell \& Pherwani, 2003; Palmer, Walls, Burgess, \& Stough, 2001; Sivanathan \& Fekken, 2002) although in other reports, these results were not replicated (Brown, Bryant, \& Reilly, 2006).

And without playing down the importance of the probable linking between EI and effective leadership styles such as TL, we believe that exceptional organizational results are also due to the strength of collective efficacy, as we shall comment on below. Therefore, one of our goals is to examine the degree of relationship between trait EI and collective efficacy.

From the viewpoint of the social cognitive theory (Bandura, 1986), self-efficacy is considered the chief construct that links abilities with performance. Self-efficacy is defined as "the beliefs in one's capabilities to organize and execute the courses of action required to produce given attainments" (Bandura, 1997, p. 3). The higher self-efficacy a person feels, the more confidence he or she will feel about successfully performing a task in a certain domain.

As self-efficacy is specific in nature, leadership selfefficacy is defined as "a person's belief that he or she can exercise leadership successfully and set a direction for teamwork and build relations with followers to gain their commitment to changing the goals..." (Paglis \& Green, 2002 , p. 216). In other words, it refers to beliefs in one's general skill to lead (Murphy, 2002). 
As noted by Hoyt (Hoyt, Murphy, Halverson, \& Watson, 2003), although efficacy is considered domain specific, this specificity should not be confused with behavioral specificity. Our analysis would be incomplete if we did not emphasize the degree of relation between efficacy beliefs at a general level, where the activities to be carried out are not delimited (leadership self-efficacy), and efficacy beliefs at a more concrete level, where a particular performance is carried out under a defined set of conditions (task self-efficacy). We therefore propose the following hypothesis:

H1-Leadership self-efficacy will affect the leader's task self-efficacy.

As group achievements are not only the product of shared knowledge and skills of the different members but also of the interactive, coordinated, and synergic dynamics of their transactions as well (Bandura, 2000), it is important to consider the contribution to performance of the group context. Bandura defined collective efficacy as "a group's shared belief in its conjoint capabilities to organize and execute the courses of action required to produce given levels of attainment" (Bandura, 1997, p. 477). That is, the cognition "Can we perform this task?" is different from the cognition "Can I do this task?" because collective efficacy includes emerging aspects that are a product of group members' interactive dynamics.

Despite this distinction between personal efficacy and collective efficacy, Bandura (1997) also proposed that collective efficacy operates through processes similar to those of personal efficacy (previous performance achievement, vicarious experience, verbal persuasion, and physiological and affective states). If collective efficacy can be affected by the same sources as self-efficacy, then an efficient leader could influence collective efficacy through these sources. In fact, some studies show an important relation between leader's efficacy and collective efficacy (Hoyt et al., 2003, Watson, Chemers, \& Preiser, 2001). This relation should also be considered within the context in which a leader directs a particular group in a specific task; as mentioned, this is a specific performance level derived from a more general level (leadership self-efficacy). Therefore, our second hypothesis is:

H2-The leader's task self-efficacy is positively related to collective task efficacy.

Much has been written about the possible effect of leader's self-efficacy on the sources of a group's collective efficacy as a means to influence such sources, but how a leader can strengthen collective efficacy is still unknown. Some authors propose verbal persuasion and modeling as efficacy sources that the leader can influence (Gist, 1987; Spink, 1990). In any case, leaders who express confidence in their directing abilities can contribute to increasing the perception of collective efficacy.

Individual differences in emotional abilities, such as coding complex emotions (Friedman \& Riggio, 1999), or the consequences of the emotional self-regulatory processes that are considered effective in interpersonal relations (Gross \& John, 2003), and have been identified in leaders' EI will probably affect the group members' collective efficacy. Therefore, we developed the following hypothesis:

H3 - Leaders' trait EI will affect collective task efficacy.

Lastly, a growing corpus of investigation has emphasized the importance of the relationship of collective efficacy with group performance (Bray, 2004; Gibson, 1999; Watson et al., 2001) to the extent that people's collective efficacy affects the way they use resources, the amount of effort devoted to the group task, and their persistence in achieving their goals (Bandura, 2000). Therefore, we propose the following hypothesis:

H4-Collective task efficacy will affect performance.

In Figure 1 are shown the hypothetical relations of the variables of the study. It can be observed that leadership self-efficacy is related to the leader's task self-efficacy. Task self-efficacy is positively related to collective task efficacy. Leader's trait EI is also related to collective task efficacy. And collective task efficacy is directly related to group performance.

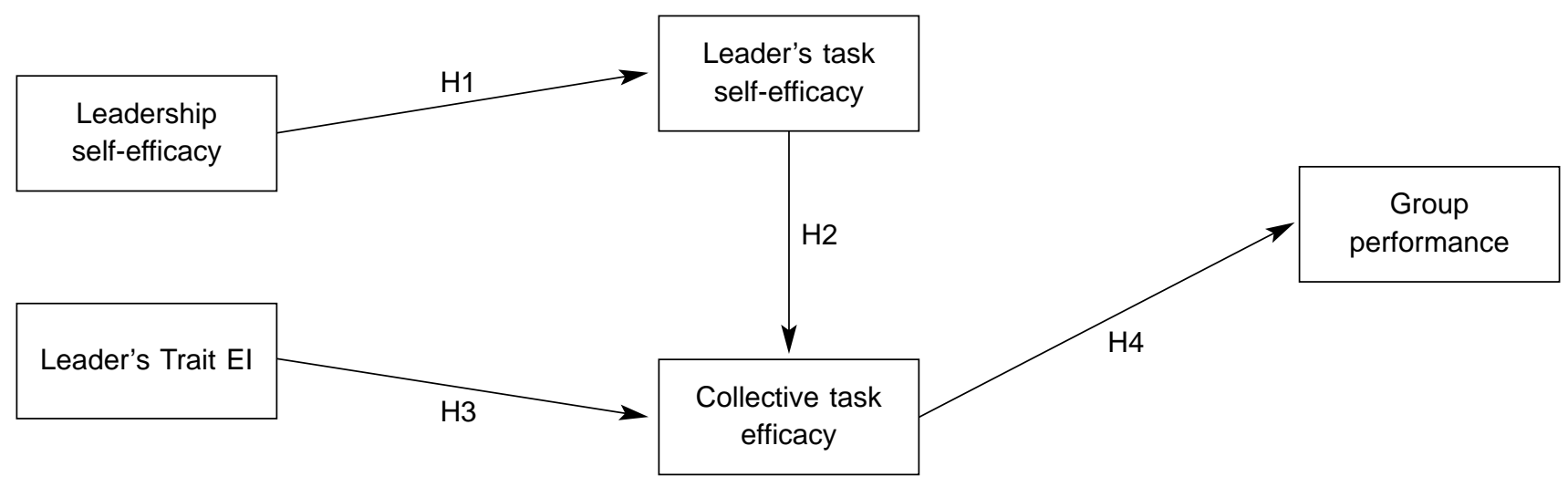

Figure 1. Theoretical model. 


\section{Method}

\section{Participants}

A total of 217 university students of psychology volunteered participated in this study in return for extra course credit. Of the sample, $83 \%$ were women, $16 \%$ were men, and $1 \%$ was unidentified. Mean age was 22.54 years ( $S D=1.85$, age range 20 to 34 years). Participants indicated on a sign-up questionnaire the time slots that fit their schedules, and researchers called to set up appointments according to participants' availability.

\section{Measures}

Measures of the following variables were performed: Emotional Intelligence, Leadership Self-Efficacy, Task SelfEfficacy, Collective Task Efficacy, and Performance.

Trait Emotional Intelligence. We used an adapted version of the Schutte Self-Report Inventory (SSRI; Schutte et al., 1998). Originally, this scale was made up of 33 items. Participants respond on a 5-point Likert type formatted scale, ranging from 1 (totally disagree) to 5 (totally agree). In their validation studies, the authors report that theoretically, the scale covers the conceptual model of Salovey and Mayer (1990). However, they suggest using a unifactorial solution of the scale (Schutte et al., 1998, p. 171). The studies that have used this version report that it is a valid and reliable measure of EI according to correlations with theoretically related constructs, group score differences, and test-retest (Ciarrochi, Chan, \& Bajgar, 2000; Ciarrochi, Deane, \& Anderson, 2002; Saklofske, Austin, \& Minski, 2003; Schutte et al., 1998, 2001). After translating the scale into Spanish, we used an interjudge criterion with five judges to analyze item adequacy to the scale content. As a result, items 7, 10, and 33 were deleted from the original scale. In fact, in Chico's (1999) study of this scale, he reported that reliability was not substantially modified when he deleted item 33 . With these modifications, the final scale was made up of 30 items.

Leadership Self-Efficacy. We elaborated a 10-item questionnaire that measures individuals' confidence in their general leadership abilities. For this purpose, we considered leaders' characteristic activities as reported by various authors (see Bass, 1985, 1990; Hackman, 1990). For example (starting with the phrase "I feel capable of...") "taking decisions that affect other people" and "mobilizing people's actions towards a certain goal." Participants were requested to respond to a series of statements, ("Yes" if they considered themselves capable of performing the content expressed in the statement and "No" if they felt no confidence about their performance). They also indicated the intensity of their confidence on a 10 -point rating scale $(1=$ minimum confidence, $5=$ moderate confidence, $10=$ maximum confidence).
Task Self-Efficacy. In order to measure leaders' confidence in their capacity to perform the commended task we used an adapted version of the Personal SelfEfficacy Scale (Riggs, Warka, Babasa, Betancourt, \& Hooker, 1994). The original scale was made up of 10 items and measures personal self-efficacy in the work setting. Therefore, some of the words that referred to "work" were changed to "task." We used 4 items from the original scale that we considered the most appropriate. Items more specifically related to the work setting were excluded, for example, "I feel threatened when others watch me work." Examples of items that were included are: "I feel confident in my ability to perform this task" and "My ability is not very much related to this task." We also formulated and added 5 items based on task activities, resulting in the final 9-item scale. Participants responded on a 5-point Likert scale, ranging from 1 (totally disagree) to 5 (totally agree).

Collective Task Efficacy. As in the above task selfefficacy scale, we used an adapted version of the Collective Efficacy Beliefs Scale (Riggs et al., 1994). This scale is based on the holistic assessment of group efficacy beliefs (Bandura, 2000), that is, this method adds the member's appraisals of the abilities of their groups operating as a whole. We used the 7 items of the original scale, adapting some words, such as "group" instead of "department." Some example items are: "The group I work with has above average abilities to perform this task" and "This group is not capable of performing as well as it should." Participants responded on a 5-point Likert scale, ranging from 1 (totally disagree) to 5 (totally agree).

Performance. Performance was assessed quantitatively (number of paper boxes produced). The subordinates produced paper boxes following the assembly instructions provided by the leader during the interaction phase (see Procedure), according to an instruction diagram.

All the self-report measures were scored by adding the items and dividing the result by the number of items.

\section{Procedure}

Task. We adapted the exercise "Using coaching and counseling skills" (Marcic, Seltzer, \& Vaill, 2001, p.153). Originally, this exercise was used to establish trust between managers and employees, using role-playing. We modified the exercise, including the leader's activity of coaching and training the followers in the task of assembling a box with sheets of paper, following the instructions of a diagram that displayed the prototype of the box. After training, each group, comprising one leader and two followers, produced as many paper boxes as possible in two different time intervals. The finished boxes that matched quality requirements (similarity to the diagram prototype) were counted at the end of each production interval. Subsequently, the quantities of boxes produced in both time intervals were 
added to make up the total performance of the group. We chose a relatively simple and routine task to allow the leader to motivate the followers.

A team member was randomly assigned to be leader. From then on, the leaders participated in the first stage of the study in a separate session from the followers.

Stage 1. The leaders completed the trait EI and leader's self-efficacy scales. They were then instructed in the assembly of the paper box, giving them a diagram with instructions and several sheets of paper to practice for 5 minutes. After this practice trial, they had 10 minutes to assemble as many boxes as possible. They were then requested to respond to the task self-efficacy scale. A total of 77 persons participated in this stage.

Stage 2. Of the 77 leaders who participated in Stage 1, 7 did not participate in this stage of interaction with the followers. Thus, 70 groups were finally formed. Each team member received specific written instructions about the activity. These instructions informed the followers about their participation in a fictitious furniture factory and that, in this session, they would be advised by the leader while they assembled paper boxes, one of the factory products. This coaching session lasted 5 minutes. Before the first production period, the leader was instructed not to play an active role in producing the boxes, but to motivate, assist, and direct the followers' work to achieve the highest possible productivity. After the coaching session, participants were given 10 minutes to produce as many boxes as possible. They were also informed that the group with the best performance (the highest production) would receive an academic reward. At the end of this production interval, the boxes were counted, and the groups were informed that they would have a second production opportunity, only lasting 5 minutes. They were told that the amount of boxes produced the first time would be added to the amount produced the second time.

The purpose of first production opportunity was to provide team members with enough task experience on which to base their collective task efficacy. Before the second opportunity, both leaders and followers completed the collective task efficacy questionnaire. After concluding the study, participants were debriefed about the nature of the experiment.

\section{Results}

\section{Descriptive Statistics, Scale Reliabilities, and Correlation Matrix}

Correlation analysis of each of the main variables was conducted to examine the main hypotheses. The mean score of the Trait EI Scale was $106.53(S D=14.35)$. The women scored higher than the men $(M=108.24, S D=10.60$ and $M=99.43, S D=23.74$, respectively, $t(70)=8.81, \mathrm{p}<.05$.). In Table 1 are shown the means, standard deviations, and scale reliabilities (Cronbach's alpha), and Table 2 shows the bivariate correlations of the predictor variables and the performance of the entire sample. Unexpectedly, leader's trait EI was significantly related to leadership self-efficacy $(r=.56, p<.01)$ and, to a lesser degree, to collective task efficacy $(r=.25, p<.05)$. Collective task efficacy was more closely related to leader's task self-efficacy $(r=.38$, $p<.01)$. As expected, group performance was strongly related to collective task efficacy $(r=.67, p<.01)$ : the higher the sense of collective efficacy, the better the group performance.

Table 1

Mean Scores, Standard Deviations, and Reliability (Cronbach's Alpha)

\begin{tabular}{lcrl}
\hline Scale & $M$ & $S D$ & $\alpha$ \\
\hline 1. Trait Emotional Intelligence & 3.42 & .46 & .88 \\
2. Leadership Self-Efficacy & 5.12 & 1.78 & .85 \\
3. Task Self-Efficacy & 3.19 & .96 & .87 \\
4. Collective Task Efficacy & 3.90 & .72 & .87 \\
\hline
\end{tabular}

Table 2

Correlations between the Variables of the Study

\begin{tabular}{|c|c|c|c|c|}
\hline Scale & 1 & 2 & 3 & 4 \\
\hline 1. Trait Emotional Intelligence & - & & & \\
\hline 2. Leadership Self-Efficacy & $.56^{* *}$ & - & & \\
\hline 3. Task Self-Efficacy & .15 & $.32 * *$ & - & \\
\hline 4. Collective Task Efficacy & $.25^{*}$ & .02 & $.38 * *$ & - \\
\hline 5. Performance & .12 & .04 & $.31 * *$ & $.67 * *$ \\
\hline
\end{tabular}

$* p<.05 . * * p<.01$. 


\section{Hypothetical Model}

In order to test the fit of the hypothetical model, we used the statistical package AMOS (Arbuckle \& Wothke, 1999) to perform an analysis of the structural equation model to examine the relations among leadership self-efficacy, task self-efficacy, trait EI, collective task efficacy, and performance.

Estimation of the general model. To estimate the hypothetical model, we used maximum likelihood estimation (MLE). The statistical fit indexes shown in Table 3 indicate that the path model was acceptable. The chi square test for the general model obtained a value of $\chi^{2}(6, N=210)=10.009, p=.124$. The value of the root mean square error of approximation (RMSEA), a measure of residual fit, was .05 . Values of .05 or less indicate a very close fit of the model (Browne \& Cudeck, 1993). The value of the comparative fit index (CFI) was .953. Values equal to or higher than .90 are considered a good fit (Arbuckle \& Wothke, 1999; Schumacker \& Lomax, 1996).

As can be seen in Figure 2, in the empirical model with standardized coefficients, our Hypothesis 3 regarding the relation between leader's trait EI and collective task efficacy was not supported. Leader's trait EI was unexpectedly related to leadership self-efficacy. Leadership self-efficacy predicted leader's task self-efficacy and this latter variable directly predicted collective task efficacy. Collective task efficacy, in turn, was the best predictor of group performance.

\section{Discussion}

In the correlational analysis of our study, trait EI showed a weak relation with the variable collective task efficacy and, in contrast, it had a higher correlation with leadership self-efficacy. In the fit of the empirical model, the significant association of trait EI with leadership self-efficacy was revealed, in a direction that was not originally foreseen in our hypotheses. On the other hand, as part of the contributions of this work, an association among generality levels of self-efficacy appraisals (e.g. Hoyt et al., 2003) was observed in the empirical model. In this line, it is logical that the influence of leadership self-efficacy on collective task efficacy is exerted through the leader's own task selfefficacy and that the final performance is determined by collective task efficacy, thus revealing the high predictive value of such collective efficacy (Bray, 2004; Gibson, 1999; Watson et al., 2001).

The fact that we did not find support for Hypothesis 3 concerning the relation between leader's trait EI and collective task efficacy might be explained by the simple nature of the task and the low degree of emotional work involved. As performance depended on the followers' coordinated activity, the most obvious influence on collective task efficacy was the leader's belief in his or her capacity to carry out the task (task self-efficacy) and transmitting this belief to the followers. The leader's specific influence on collective efficacy would have been more obvious if the leader had played an active role in one of the sources of

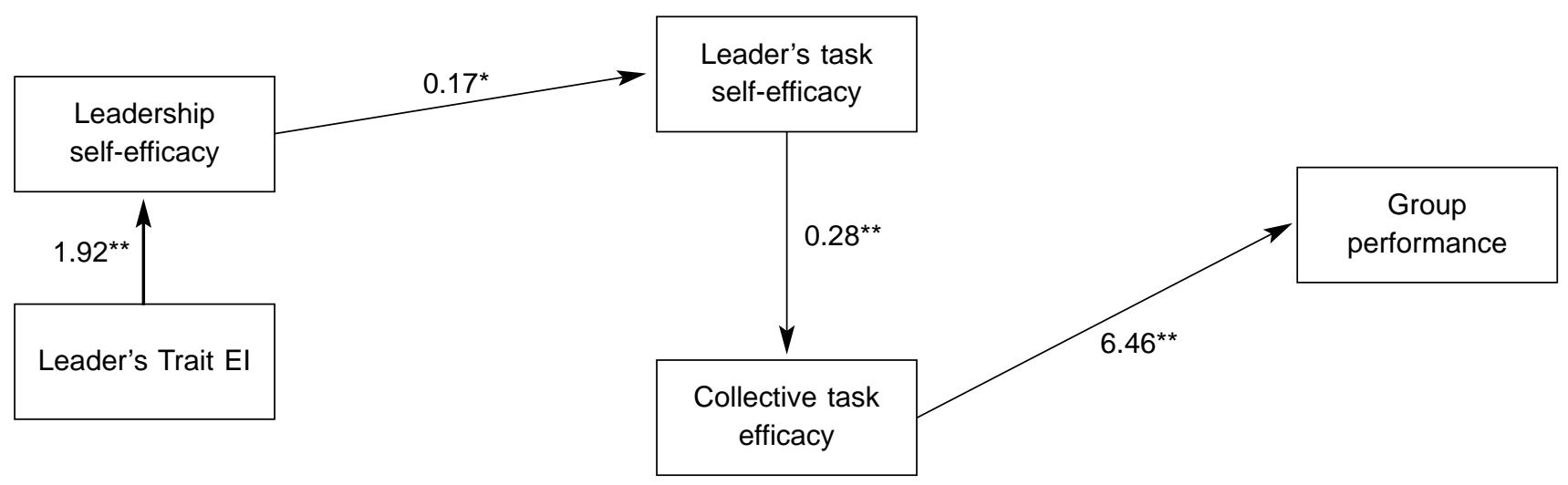

Figure 2. Empirical model for the general sample with standardized path coefficients. ${ }^{*} p<.003 .{ }^{* *} p<.001$.

Table 3

Goodness-of-fit Statistics for the Proposed Model (Maximum Likelihood Estimation)

\begin{tabular}{lcccccc}
\hline Model & $\chi^{2}$ & $d f$ & NFI & TLI & CFI & RMSEA \\
\hline Null model & 10.009 & 6 & .90 & .883 & .953 & 0.5 \\
\hline
\end{tabular}

Note . NFI = normed fit index TLI = Tucker-Lewis index; $\mathrm{CFI}=$ comparative fit index; RMSEA = root mean square error of approximation. 
efficacy. For example, let us examine the case of emotional arousal as a source of efficacy. Bandura (1997) stated that the effect of emotional arousal will depend on whether the subject values the condition as positive or negative, as well as the level of achievement that the individual hopes to reach in a certain task. Bandura argues that the effect of the arousal will be different depending on the type of task. If the task is easy to learn, high emotional arousal will facilitate it, but high arousal will hinder the task if it is more difficult to learn. In this condition, the leader could exert his or her influence on the followers' efficacy beliefs by modifying their positive or negative perception of the emotional arousal of a task in a given situation.

One of the limitations of this work is the kind of sample employed. In this study, there was a predominance of women and a significant difference between men's and women's mean trait EI scores (this is consistent with other investigations, see Bracket, Mayer, \& Warner, 2004; Ciarrochi et al., 2000; Mayer et al., 1999; Schutte et al., 1998). In view of recent evidence of the association of leadership styles and EI, one wonders whether the gender differences in emotional abilities may influence the use of different leadership styles that involve specific behaviors in certain tasks or contexts. Wong and Law (2002), for example, found a significant interaction between followers' EI, emotional tasks, and performance. Whether or not gender differences in the scores correspond to differences in ability of certain dimensions of EI should also be examined.

Another possible methodological disadvantage of our study is that associated with self-report measures (for a review of the advantages and disadvantages of EI measures, see Extremera \& Fernández-Berrocal, 2004), such as the problem of social desirability, so that distortions reflected in subjects' highest scores should be foreseen. The significant relation between trait EI and leadership self-efficacy indicates the possibility of overlap of these constructs. Feeling capable of influencing a group may overlap the perception of managing other peoples' emotions.

The results might have been different if we had used a measure of EI ability, although it is prudent to qualify an aspect about the way it is assessed. For example, if emotional coping is considered a key ability in interpersonal influence, it is surprising that the measurement of this dimension with a measure of EI ability receives the same criticism as the measures of trait EI because it is difficult to classify a response about emotional coping as correct when it is an inherently subjective emotional experience. Lopes et al. (2003) admit that measures of EI ability may not cover all the abilities that contribute to people's capacity to regulate their emotions.

Currently, organizations are immersed in a very volatile context, and they have gone from traditional hierarchical structures to structures based on teams. Because of this and of advances in knowledge of the role of emotions in the work setting, it is essential to study in depth the influence of leaders' emotional status on the group process. Authors like Pescosolido (2002) suggest that one of the leader's roles is to serve as "emotional managers." The results of research on EI in the organizational area are still difficult to interpret, partly because it is necessary to reach a consensus about the EI construct and how to measure it. Although in our study we could not observe the effects of leader's trait EI on collective efficacy, we agree with other authors about the usefulness of persistent investigation of EI because of its potential utility as a predictor of organizational results (Law et al., 2004; Van Rooy \& Viswesvaran, 2004). We believe that future research on trait EI and leadership should include external observers to reduce the bias of the shared variance method, as well as adopting a specific gender perspective to take into account differences in organizational variables and in perceptions of EI (Petrides \& Furnham, 2006).

\section{References}

Arbuckle, J.L., \& Wothke, W. (1999). Amos 4.0 users' guide. Chicago, IL: SPSS.

Bandura, A. (1986). Social foundations of thought and action: A social cognitive theory. Englewood Cliffs, NJ: Prentice-Hall.

Bandura, A. (1997). Self-Efficacy: The exercise of control. New York: Freeman

Bandura, A. (2000). Exercise of human agency through collective efficacy. Current Directions in Psychological Science, 9, 7578.

Barchard, K.A. (2003). Does emotional intelligence assist in the prediction of academic success? Educational and Psychological Measurement, 63, 840-858.

Bar-On, R. (1997). The emotional quotient inventory (EQ-i): A test of emotional intelligence. Toronto: Multi-Health Systems.

Bass, B.M. (1985). Leadership: Good, better, best. Organizational Dynamics, 3, 26-40.

Bass, B.M. (1990). Bass and Stodgill's handbook of leadership. New York: Free Press.

Boyatzis, R., Goleman, D., \& Rhee, K. (2000). Clustering competence in emotional intelligence: Insights from the emotional competence inventory (ECI). In R. Bar-On \& J.D.A. Parker (Eds.), Handbook of emotional intelligence (pp. 343362). San Francisco: Jossey-Bass.

Brackett, M.A. \& Mayer, J.D. (2003). Convergent, discriminant, and incremental validity of competing measures of emotional intelligence. Personality and Social Psychology Bulletin, 29, 1147-1158.

Brackett, M.A., Mayer, J.D., \& Warner, R.M. (2004). Emotional intelligence and its relationship to everyday behaviour. Personality and Individual Differences, 36, 1387-1402.

Brackett, M.A. \& Salovey, P. (2006). Measuring emotional intelligence with the Mayer-Salovey-Caruso Emotional Intelligence Test (MSCEIT). Psicothema, 18 (Suppl. 1), 3441. 
Bray, S.R. (2004). Collective efficacy, group goals, and group performance of a muscular endurance task. Small Group Research, 35, 230-238.

Brown, F.W., Bryant, S.E., \& Reilly, M.D. (2006). Does emotional intelligence-as measured by the EQI-influence transformational leadership and/or desirable outcomes? Leadership \& Organization Development Journal, 27, 330351.

Brown, F.W., \& Moshavi, D. (2005). Transformational leadership and emotional intelligence: A potential pathway for an increased understanding of interpersonal influence. Journal of Organizational Behavior, 26, 867-871.

Browne, M.W., \& Cudeck, R. (1993). Alternative ways of assessing model fit. In K.A. Bollen \& J.S. Long (Eds.), Testing structural equation models (pp. 136-162). Newbury Park, CA: Sage.

Caruso, D.R., Mayer, J.D., \& Salovey, P. (2002). Emotional intelligence and emotional leadership. In R.E. Riggio, S.E. Murphy, \& F.J. Pirozzolo (Eds.), Multiple intelligences and leadership (pp. 55-74). Mahwah, NJ: Erlbaum.

Chico, E. (1999). Evaluación psicométrica de una escala de inteligencia emocional. Boletin de Psicología, 62, 65-78.

Ciarrochi J., Chan A.Y.C., \& Bajgar J. (2000). Measuring emotional intelligence in adolescents. Personality and Individual Differences, 31, 1105-1119.

Ciarrochi, J.V., Chan, A.Y.C., \& Caputi, P. (2000). A critical evaluation of the emotional intelligence construct. Personality and Individual Differences, 28, 539-561.

Ciarroci, J., Deane, F.P., \& Anderson, S. (2002). Emotional intelligence moderates the relationship between stress and mental health. Personality and Individual Differences, 32, 197-209.

Daus, K.S., \& Ashkanasy, N.M. (2005). The case for the abilitybased model of emotional intelligence in organizational behavior. Journal of Organizational Behavior, 26, 453-466.

Derksen, J., Kramer, I., \& Katzko, M. (2002). Does a self-report measure for emotional intelligence assess something different than general intelligence? Personality and Individual Differences, 32, 37-48.

Downey, L.A., Papageorgiou, V., \& Stough, C. (2006). Examining the relationship between leadership, emotional intelligence and intuition in senior female managers. Leadership \& Organization Development Journal, 27, 250-264.

Extremera, N., \& Fernández-Berrocal, P. (2004). El uso de las medidas de habilidad en el ámbito de la inteligencia emocional. Boletín de Psicología, 80, 59-77.

Extremera, N., Fernández-Berrocal, P., Mestre, J.M., \& Guil, R. (2004). Medidas de evaluación de la inteligencia emocional. Revista Latinoamericana de Psicología, 36, 209-228.

Friedman, H.S., \& Riggio, R.E. (1999). Individual differences in ability to encode complex affects. Personality and Individual Differences, 27, 181-194.

George, J.M. (2000). Emotions and leadership: The role of emotional intelligence. Human Relations, 53, 1027-1055.

Gibson, C.B. (1999). Do they do what they believe they can? Group efficacy and group performance across tasks and cultures. Academy of Management Journal, 42, 138-152.
Gist, M.E. (1987). Self-Efficacy: Implications for organizational behavior and human resource management. Academy of Management Review, 12, 472-485.

Goldenberg, I, Matheson, K., \& Mantler, J. (2006). The assessment of emotional intelligence: A comparison of performance-based and self-report methodologies. Journal of Personality Assessment, 86, 33-45.

Gross, J.J., \& John, O.P. (2003). Individual differences in two emotion regulation processes: Implications for affect, relationships, and well-being. Journal of Personality and Social Psychology, 85, 348-362.

Hackman, J.R. (1990). Groups that work (and those that don't. San Francisco, CA: Jossey-Bass.

Hoyt, C., Murphy, S.E., Halverson, S.K., \& Watson, C.B. (2003). Group leadership: Efficacy and effectiveness. Group Dynamics: Theory, Research and Practice, 7, 259-274.

Kerr, R., Garvin, J., Heaton, N., \& Boyle, E. (2006). Emotional intelligence and leadership effectiveness. Leadership \& Organization Development Journal, 27, 265-279.

Law, K.S., Wong, C.S., \& Song, L.J. (2004). The construct and criterion validity of emotional intelligence and its potential utility for management studies. Journal of Applied Psychology, $89,483-496$.

Leban, W., \& Zulauf, C. (2004). Linking emotional intelligence abilities and transformational leadership styles. The Leadership \& Organization Development Journal, 25, 554-564.

Lopes, P.N., Salovey, P., \& Straus, R. (2003). Emotional intelligence, personality, and the perceived quality of social relations. Personality and Individual Differences, 35, 641-658.

Mandell, B., \& Pherwani, S. (2003). Relationship between emotional intelligence and transformational leadership style: A gender comparison. Journal of Business and Psychology, 17, 387-402.

Marcic, D., Seltzer, J., \& Vaill, P. (2001). Organizational behavior: Experiences and cases. Cincinnati, $\mathrm{OH}$ : South-Western College Publishing.

Mayer, J.D, Caruso, D.R., \& Salovey, P. (1999). Emotional intelligence meets traditional standards for an intelligence. Intelligence, 27, 267-298.

Mayer, J.D., \& Salovey, P. (1997). What is emotional intelligence? In P. Salovey, \& D. Sluyter (Eds.), Emotional development and emotional intelligence: Implications for educators (pp. 3-31). New York: Basic Books.

Mayer, J.D., Salovey, P., \& Caruso, D.R. (2000). Models of emotional intelligence. In R.J. Sternberg (Ed.), The handbook of intelligence (pp. 396-420). Cambridge, UK: Cambridge University Press.

Mayer, J.D., Salovey, P., \& Caruso, D.R. (2001). Technical manual for the MSCEIT v. 2.0. Toronto. Canada: MHS Publishers.

Murphy, S.E. (2002). Leader self-regulation: The role of selfefficacy and multiple intelligences. In R.E. Riggio, S.E. Murphy, \& F.J. Pirozzolo (Eds.), Multiple intelligences and leadership (pp. 163-186). Mahwah, NJ: Erlbaum.

O'Connor, R.M., \& Little, I.S. (2003). Revisiting the predictive validity of emotional intelligence: Self-report versus ability-based measures. Personality and Individual Differences, 35, 1893-1902. 
Paglis, L.L., \& Green, S.G. (2002). Leadership self-efficacy and manager's motivation for leading change. Journal of Organizational Behavior, 23, 215-235.

Palmer, B., Walls, M., Burgess, Z., \& Stough, C. (2001). Emotional intelligence and effective leadership. Leadership \& Organization Development Journal, 22, 5-10.

Pérez, J.C., Petrides, K.V., \& Furnham, A. (2005). Measuring trait emotional intelligence. In R. Schulze \& R.D. Roberts (Eds.), International handbook of emotional intelligence (pp.181201).Cambridge, MA: Hogrefe \& Huber

Pescosolido, A.T. (2002). Emergent leaders as managers of group emotion. The Leadership Quarterly, 13, 583-599.

Petrides, K.V., \& Furnham, A. (2001). Trait emotional intelligence: Psychometric investigation with reference to established trait taxonomies. European Journal of Personality, 15, 425-448.

Petrides, K.V., \& Furnham, A. (2006). The role of trait emotional intelligence in a gender-specific model of organizational variables. Journal of Applied Social Psychology, 36, 552-569.

Riggs, M., Warka, J., Babasa, B., Betancourt, R., \& Hooker, S. (1994). Development and validation of self-efficacy and outcome expectancy scales for job-related applications. Educational and Psychological Measurement, 54, 793-802.

Rosete, D., \& Ciarrochi, J. (2005). Emotional intelligence and its relationship to workplace performance outcomes of leadership effectiveness. Leadership \& Organization Development Journal, 26, 388-399.

Saklofske, D.H., Austin, E.J., \& Minski, P.S. (2003). Factor structure and validity of a trait emotional intelligence measure. Personality and Individual Differences, 34, 707-721.

Salovey, P., \& Mayer, J.D. (1990). Emotional intelligence. Imagination, Cognition, and Personality, 9, 185-211.

Salovey, P., Mayer, J.D., Goldman, S., Turvey, C., \& Palfai, T. (1995). Emotional attention, clarity, and repair: Exploring emotional intelligence using the Trait Meta-Mood Scale. In
J.W. Pennebaker (Ed.), Emotion, disclosure, and health (pp. 125-154). Washington, DC: American Psychological Association.

Schumacker, R.E., \& Lomax, R.G. (1996). A beginner's guide to structural equation modeling. Mahwah, NJ: Erlbaum.

Schutte, N.S., Malouff, J.M., Bobnik, C., Coston, T.D., Greeson, C., Jedlicka, C., Rhodes, E., \& Wendorf, G. (2001). Emotional intelligence and interpersonal relations. Journal of Social Psychology, 141, 523-536.

Schutte, N.S., Malouff, J.M., Hall, L.E., Haggerty, D.J., Cooper, J.T., Golden, C.J., \& Dorheim, L. (1998). Development and validation of a measure of emotional intelligence. Personality and Individual Differences, 25, 167-177.

Sivanathan, N., \& Fekken, G.C. (2002). Emotional intelligence, moral reasoning and transformational leadership. Leadership \& Organization Development Journal, 23, 198-204.

Spink, K.S. (1990). Group cohesion and collective efficacy of volleyball teams. Journal of Sport Exercise Psychology, 12, 301-311.

Van Rooy, D.L., \& Viswesvaran, C. (2004). Emotional intelligence: A meta-analytic investigation of predictive validity and nomological net. Journal of Vocational Behavior, 65, 71-95.

Warwick, J. \& Nettelbeck, T. (2004). Emotional intelligence is...? Personality and Individual Differences, 37, 1091-1100.

Watson, C.B., Chemers, M.M., \& Preiser, N. (2001). Collective efficacy: A multilevel analysis. Personality and Social Psychology Bulletin, 27, 1057-1068.

Wong, C., \& Law, K.S. (2002). The effects of leader and follower emotional intelligence on performance and attitude: An exploratory study. The Leadership Quarterly, 13, 243-274.

Received July, 17, 2006

Revision received January, 22, 2007

Accepted February, 7, 2007 